\title{
Review
}

\section{Replacing Dopamine Neurons in Parkinson's Disease: How did it happen?}

\author{
Anders Björklund ${ }^{\mathrm{a}, *}$ and Olle Lindvall ${ }^{\mathrm{b}, *}$ \\ ${ }^{a}$ Department of Experimental Medical Science, Wallenberg Neuroscience Center, Lund, Sweden \\ ${ }^{\mathrm{b}}$ Department of Clinical Sciences, and Lund Stem Cell Center, Division of Neurology, University Hospital, \\ Lund, Sweden
}

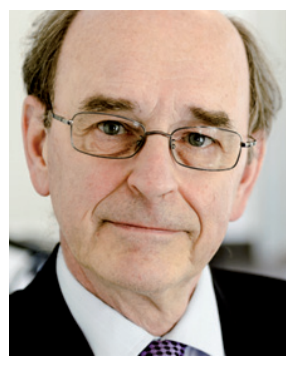

Anders Björklund received his PhD at Lund University in 1969, and has spent his entire academic career at this institution. He was elected member of the Royal Swedish Academy of Sciences in 1989, and Foreign Member of the National Academy of Sciences, USA, in 2011. His main research interests are in studies of brain regeneration and repair, with a focus on cell replacement and gene therapy in neurodegenerative diseases. Bjorklund's team has pioneered the use of cell transplantation for restoration of dopamine fuction in Parkinson's disease, and is currently playing an active role in the exploration of stem cells for this purpose.

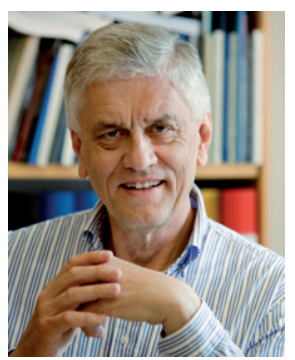

Olle Lindvall received his Ph.D. in 1974 and M.D. in 1978 and became Professor and Senior Consultant in clinical neurology at Lund University Hospital, Sweden, in 1992. He is Senior Professor since 2014. He was leading the clinical cell transplantation program for Parkinson's patients at Lund University between 1983 and 2012. This program pioneered the use of neuronal replacement as a novel strategy to restore function in the diseased human brain. Lindvall's laboratory is working with transplantation of stem cells and reprogrammed cells and neurogenesis in neurodegenerative disorders. He is an elected member of the Royal Swedish Academy of Sciences.

\footnotetext{
*Correspondence to: Anders Björklund, Wallenberg Neuroscience Center, Department of Experimental Medical Science, SE-22184 Lund, Sweden. E-mail: anders.bjorklund@med.lu.se and Olle Lindvall, Division of Neurology, Department of Clinical Sciences, and Lund Stem Cell Center, University Hospital, SE-221 85 Lund, Sweden. Tel.: AB: +4646 2220540; OL: +4646 2220543; E-mail: olle.lindvall@med.lu.se.
} 


\begin{abstract}
The efforts to develop a dopamine cell replacement therapy for Parkinson's disease have spanned over more than three decades. Based on almost 10 years of transplantation studies in animal models, the first patients receiving grafts of fetal-derived dopamine neuroblasts were operated in Lund in 1987. Over the following two decades, a total of 18 patients were transplanted and followed closely by our team with mixed but also very encouraging results. In this article we tell the story of how the preclinical and clinical transplantation program in Lund evolved. We recall the excitement when we obtained the first evidence for survival and function of transplanted neurons in the diseased human brain. We also remember the setbacks that we have experienced during these 30 years and discuss the very interesting developments that are now taking place in this exciting field.
\end{abstract}

Keywords: Transplantation, brain repair, fetal tissue, stem cells

Our interest in cell transplantation in the brain goes back to the 1970ies when access to new microscopic techniques and lesioning methods - in our case the Falck-Hillarp monoamine histofluorescence method [1] and the neurotoxin lesion model of Parkinson's disease (PD) [2]- opened up entirely new possibilities to monitor the survival, growth, and function of neurons implanted into the brain. Pioneering studies by Olson and Seiger in the anterior eye chamber [3] and by Das and Altman in the cerebellum of neonatal rats [4] stimulated one of us (A.B.) to explore this idea in adult rats with the goal to determine the conditions under which early postmitotic neuroblasts, obtained from the developing brain, could be made to survive and integrate into the brain of adult rats [5]. The most striking finding in these early studies was the remarkable capacity of grafted catecholaminergic and cholinergic neurons to grow new axonal connections over long distances and restore lost innervation patterns with high accuracy in areas of the brain previously deprived of their intrinsic afferent innervations [6-8].

The dopamine projection system was a primary interest in our lab and it was obvious, therefore, that we should explore the possibility to use the transplantation approach to "repair" lesions involving this system. The now classic 6-hydroxydopamine (6-OHDA) lesion model of PD, introduced by Ungerstedt and Arbuthnott a few years earlier [2], gave us an interesting experimental tool to study not only the growth capacity of grafted ventral mesencephalic (VM) dopamine neuroblasts but also the functional capacity of such transplants in a model that replicated the core pathology of the disease. The 6-OHDA model, based on injection of the toxin directly into the nigro-striatal bundle, was ideally suited for our purpose: the behavioral deficits were profound and stable over many moths, and the lesion could be delivered unilaterally which made possible studies of functional impairment and recovery on the lesioned and grafted side in direct comparison with the non-lesioned side. In addition, the turning behavior induced by the dopamine-releasing drug amphetamine provided a convenient test to assess the magnitude of dopamine neuron cell loss, and loss of striatal innervation, induced by the toxin, as well as the survival and function of the grafted cells. Our studies using this model started in 1978 and has since then kept us busy over nearly four decades.

For one of us (O.L.), who had started to work as a clinical neurologist in 1976, it was obvious that there was at that time a clear need for new therapeutic approaches for a large group of PD patients. L-dopa treatment initially provided a marked symptomatic relief in most cases, but within 5 to 10 years, most patients showed a progressive loss of efficacy of L-dopa assciated with diurnal oscillations in motor performance ("on-off" phenomena) and dyskinesias. Although at this stage the patients often temporarily benefitted from changes in medication, most patients became severely incapacitated.

The editors of JPD have asked us to identify our publications that mark the most critical developments of transplantation as a potential cell replacement therapy in PD. We have selected four: In the preclinical work leading up to the first clinical trial, the 1979 Björklund \& Stenevi paper [9] reporting our first successful grafting of fetal VM tissue in the rat 6-OHDA lesion model, and the 1983 report, published as a 5-part paper in a supplement to Acta Physiologica Scandinavica [10] where we introduced the intra-parenchymal transplantation method using dissociated cell suspensions. This grafting technique, which was later used in the clinical trials, made it possible to target deep structures and achieve for the first time recovery of both drug-induced and spontaneous sensori-motor behavior in rats with either unilateral and bilateral 6-OHDA lesions of the midbrain dopamine system. In the clinical program, our 1990 Science paper [11] in which we published the 
first evidence that human intra-parenchymal fetal VM grafts can survive and grow in the brains of PD patients, and our 1999 article in Nature Neuroscience [12] in which we demonstrated for the first time complete restoration of dopamine synthesis and release in the grafted putamen associated with major clinical improvement, allowing for withdrawal of L-dopa treatment for several years. In the following sections we will summarise the work that led up to these seminal publications and discuss their impact in the perspective of the developments that have taken place in this field over the subsequent decades.

\section{THE EARLY EXPERIMENTAL WORK}

The approach we adopted in our first experiments was to create a cavity in the cerebral cortex which could serve as a "culturing chamber" where the exposed vessel-rich surface of the underlying choroidal fissue could serve as a source of rapid vascularization. Small pieces of tissue dissected from the fetal brain were implanted, including either of the three major monoaminergic neuron types: dopamine neurons from the developing VM, noradrenaline neurons from the developing pons, and serotonin neurons from the developing brain stem raphe region. The results of this first round of experiments, published in 1976 [5, 6], showed that the grafted neurons survived well provided that they were obtained at the neuroblast stage (16-17 days of gestation in this case), and that grafts placed adjacent to the previously denervated hippocampus had the capacity to grow and generate a new extensive innervation of the denervated host hippocampus and dentate gyrus. However, our first attempt to graft VM dopamine neurons to a cavity overlying the striatum failed: Of the 20 transplants studied in this group only 1 survived, cantaining only few viable dopamine neurons [5].

We concluded that the poor outcome in this experiment was due to insufficient vascular support of the grafted tissue pieces. So in the next round we devised a two-step procedure where the transplants were inserted into the cavity with a 3-4 weeks delay, i.e. at the time when a new vessel-rich bed had formed at the bottom of the cavity. This time the transplants showed excellent long-term survival. They contained up to 4000 surviving dopamine neurons and provided the previously denervated striatum with an extensive new innervation that covered up to one third of the head of the caudate-putamen. Motor asymmetry, monitored monthly by the amphetamine rotation test, was completely reversed in these animals. Strikingly, this functional effect was seen to develop gradually with a time-course that matched the progressive extension of the graft-derived reinnervation of the host striatum, as visualised with the histofluorescence method. In one group of fully compensated rats, the transplant was removed (by suction) 6 months after transplantation. In these rats the original motor asymmetry deficit re-appeared within 4 days, confirming that the functional recovery indeed was graft-induced. We published these initial findings in Brain Research, which was the leading archival neuroscience journal at the time, first as a short preliminary report in 1979 [9] followed by a more substantial paper in 1980 [13].

Excited by our findings we initially submitted the first of these two papers to Science, but to our surprise, while our paper was still under review, a similar study appeared in Science [14]. Being too similar, the editors kindly declined our paper, and we rushed to have it published in Brain Research instead. This competing study was performed by a young US investigator, Mark Perlow, who at the time was working as a student in Richard Wyatt's lab at the NIH and collaborating with the Karolinska team. It was based on the same idea but the approach was different: the VM tissue was implanted into the lateral ventricle, in contact with the medial surface of the denervated caudate-putamen. These transplants turned out to be quite small, and in contrast to the effective re-innervation seen in our transplanted animals, the growth of axons from the intraventricular transplants into the striatum was quite limited. While our study suggested that the grafted of fetal dopamine neurons worked through the establishment of a new functional "nigro-striatal" connection able to compensate for the loss dopamine innervation in the toxin-lesioned animals, the observations reported in the Perlow et al. study suggested an entirely different functional mechanism. In the Perlow et al. study the functional response induced by the intraventricular transplants was monitored by the reduction in apomorphine-induced turning, known to depend on the presence of supersensitive dopamine receptors present in the denervated striatum. The reduced turning behavior seen in animals with intraventricular transplants, therefore, was most likely due to normalisation of receptor sensitivity by dopamine diffusing from the ventricle into the striatal parenchyma, and thus independent of any graft-host axonal connectivity. This interpretation of the observations made in Perlow et al. study was further corroborated in a subsequent study by the same team showing that a similar 
reduction of apomorphine-induced turning could be obtained by intra-ventricular transplants of adrenal chromaffin cells, i.e. by cells lacking any axonal projections [15].

At this time Steve Dunnett, a PhD student in Susan Iversen's lab in Cambridge, UK, had joined our team and in 1981 we published jointly four additional papers as a follow-up to our first two articles. Collectively, these studies provided an extended analysis of the survival, growth and functional effects of fetal VM transplants, as seen in rats with either unilateral or bilateral 6-OHDA lesions of the nigro-striatal pathway, and in a paper published in Nature in 1981 [16] we went on to propose a mechanistic model of dopamine graft function that helped to explain why dopamine neurons placed in the striatum, i.e. in an ectopic position, could be effective in restoring function in the dopamine-depleted striatum.

\section{DEVELOPMENT OF THE CELL SUSPENSION TECHNIQUE AND STEPS TOWARD THE CLINIC}

Our initial findings obtained with the cavitytransplant model provided compelling data in support of the idea that grafts of fetal dopamine neurons could be used to establish a new functional "nigro-striatal" connection able to compensate for the lost dopamine innervation in the toxin lesioned animals. Nevertheless, the cavity surgery used in these studies had an obvious weakness in that it involved major damage to the overlying cortex. And there was another snag: the functional effect seen in these animals was limited to recovery in motor asymmetry, and the severe and characteristic impairment in spontaneous sensorimotor behaviour induced by the 6-OHDA lesion was not affected. Steve suggested that this shortcoming could be due to the fact that the new innervation extending from the intra-cortical grafts was limited to the dorsal part of the head of the caudate-putamen. In his ongoing thesis work Steve had shown that the striatum is functionally heterogenous and that it is the ventral-lateral sector, i.e. the part corresponding to the putamen in humans, that is specifically involved in the regulation of sensori-motor behavior [17]. Thus more complete functional recovery may require more widespread re-innervation of the striatal complex. We had already started to work on a different transplantation technique based on the injection of dissociated cell suspensions which would allow grafting to deep brain sites, as well as multiple graft placements, and thus offer the possibility to obtain more widespread and complete dopamine reinnervation of the striatum.

Thus, in 1981 we abandoned the cavity transplantation procedure in favor of a less invasive technique based on stereotaxic injections of dissociated cell suspensions directly into the brain parenchyma. The initial results we obtained with this approach were very promising $[18,19]$, and in collaboration with Steve and Rusty Gage, who had now joined as a postdoc in the lab, we set out to further optimise this technique and evaluate its potential, resulting in a series of experiments that was published (in 5 parts) as a supplement to Acta Physiological Scandinavica in 1983 [10]. The results showed that the cell suspension approach made it possible to distribute the graft tissue over multiple sites (up to five in these experiments) and achieve more extensive reinnervation of the striatum, combined with near complete recovery of both drug-induced and spontaneous sensori-motor behavior, as seen in rats with either unilateral or bilateral 6-OHDA lesions. The same year a very talented medical student, Patrik Brundin, joined the lab as a $\mathrm{PhD}$ student, and his first job was to work out the technical parameters for optimal viability of dissociated VM tissue [20]. At the same time we initiated a process that would give us permission to use VM tissue from aborted human fetuses for transplantation, which would allow us to perform the necessary preclinical studies with human fetal tissue in our animal model. We received approval from the local research ethics committe in 1985, and in March 1986 the Swedish Society of Medicine adopted guidelines for the use of human fetal tissue for transplantation purposes that were later incorporated into Swedish law.

In three papers published in Experimental Brain Research [21-23] we showed that human fetal VM tissue from 6-9 week old aborted fetuses survived well after transplantation to the striatum, provided that the animals were immunosuppressed by daily injections of cyclosporine. The grafted neurons were efficient in re-innervating the previously denervated striatum, reverse amphetamine-induced rotation, restore dopamine release, and form normal synaptic contacts with the host striatal projection neurons. In these experiments we were also able to identify the appropriate landmarks to be used for dissection of the dopamine-rich ventral midbrain tissue. In parallel, and in collaboration with labs in Stockholm, Marseille and Oxford, we performed a series of studies of rat-to-rat VM cell suspension transplants using microdialysis and in vivo voltammetry to 
monitor the extent of recovery of dopamine release, and we used electron microscopy and tract-tracing techniques to study the integration of the grafted dopamine neurons into host striatal circuitry, and the synapses made by the outgrowing axons onto denervated striatal projection neurons in the host.

\section{THE FIRST CLINICAL TRIALS}

Already the early reports of behavioral recovery following implantation of dopamine-rich fetal VM tissue in 6-OHDA-treated rats had obvious clinical implications, raising the possibility that the dopamine cell replacement approach could be possible to develop to a transplantation therapy for PD patients. However, from a clinical perspective, there were two main problems: First, the practical one. Would it be possible to collect sufficient amounts of human fetal brain tissue from routine induced abortions, avoiding contamination, identify the VM containing the dopamine neurons and then implant the tissue into the PD patient's brain without adverse effects? Second, and most important, the ethical problem. Would it be ethically and morally acceptable to collect and use tissue from aborted human fetuses for intracerebral transplantation in PD patients in order to ameliorate their motor symptoms? At that time, no guidelines for the use of such tissue were available.

Already in 1982 and 1983, the first intracerebral transplantations in patients with PD in the world were carried out. Instead of fetal VM tissue, Lars Olson together with Åke Seiger and Erik-Olof Backlund at the Karolinska Institute implanted two patients with tissue from their own adrenal medulla into the caudate nucleus [24]. This pioneering clinical experiment was based on the paper in Nature, mentioned above, providing some evidence that catecholamines secreted from transplanted adrenal medulla tissue could reduce a rotational deficit in a rodent PD model. In April 1985, another two PD patients received autologous adrenal medullary grafts at the University Hospital in Lund as a collaboration between one of us (O.L.) and the Stockholm group [25]. Compared to the first transplantations, two major changes were introduced: First, more careful and extensive, repeated neurological assessments including, e.g., quantitative, timed tests of motor performance in the different extremities, in order to detect also minor and focal motor improvements. Second, implantation of the tissue into the putamen instead of the caudate with the objective to improve motor function.
The outcome in these two patients with adrenal medulla grafts in the putamen was reported (by O.L.) at a meeting at the New York Academy of Sciences in April 1986. The patients had exhibited a transient improvement of motor function, primarily on the side of the body contralateral to the graft. The reaction of the audience to the talk was overtly negative. However, in our view, the study had given some valuable information. First, that it was possible to implant cells in the human putamen without adverse effects. Second, that our assesment protocol and test battery could detect small changes in motor function in PD patients. But was it possible to move forward with clinical transplantations when the recommendations from the meeting were to wait until many years of preclinical experiments including studies in monkeys had been performed? We shared a hotel room during the meeting and we discussed this a lot during the night following the talk. During that night we decided to go ahead with our clinical transplantation program using human fetal VM tissue despite the resistance from the scientific and clinical community.

The planning of the first transplantations with human fetal VM tissue was carried out by a team that included researchers from Karolinska Institute, Lars Olson, Åke Seiger, Ingrid Strömberg and ErikOlof Backlund, and from Lund, Patrik Brundin, Stig Rehncrona, Håkan Widner, Birger Åstedt and ourselves. During this period and after several hearings and discussions, guidelines for the use of human fetal tissue for transplantation purposes were adopted by the Swedish Society of Medicine in March 1986. This was a very important development. Together with approval from local ethical committees, it was now possible both to perform the necessary preclinical studies with human VM tissue grafted into animal models and to move forward to the clinic. As mentioned above, a crucial step in the clinical translation was that we demonstrated, in studies that formed part of Patrik Brundin's PhD thesis, that dopamine neurons from 6 to 9 week old aborted human fetuses survive, reinnervate the striatum and ameliorate deficits after intrastriatal transplantation in dopamine-denervated rats [21-23].

One particularly important planning meeting took place in London in June 1986 when we met with the leading movement disorder specialist in the world, David Marsden, from the Institute of Psychiatry and the imaging expert, Richard Frackowiak, from the Hammersmith Hospital. The aim was to discuss the possibility of detecting a surviving dopamine cell graft in the brain of a living PD patient. We regarded 
this to be crucial to understand what was happening after the implantation of fetal tissue and to clarify the mechanisms of any possible improvement. Would available methods have the necessary resolution and sensitivity to demonstrate survival of grafted dopamine neurons? Nothing like this had ever been tried before. The conclusion from the meeting was that there might be a chance that a surviving graft would be detected by positron emission tomography (PET) using ${ }^{18} \mathrm{~F}$-fluoro-dopa as tracer.

In September 1987, O.L. traveled with the first two patients to London for preoperative PET scans at Hammersmith Hospital. In order to avoid all movements during the PET scanning, the patient's head was placed in a helmet which had been specially made for that person. Then the patient had to lie down on his/her back for several hours without having taken their antiparkinsonian medication. It was very important that we got as much data as possible. This was very tough for these severely disabled patients who were really heroes! When the first scanning had been completed, we celebrated with a bottle of champagne and we all cheered and were very happy. However, during the night, much of the data were lost due to computer failure.

The two patients were operated on November 10 and December 8, 1987, respectively. Our neurosurgeon Stig Rehncrona implanted VM tissue from four fetal donors unilaterally along 2 tracts in the putamen and one tract in the head of the caudate nucleus. The surgeries went well and the patients were monitored extensively including PET scanning at 6 months. We had decided that the first report of the outcome of the transplantations should be given at the International Parkinson symposium in Jerusalem in 1988. Nothing should leak out earlier. The meeting in Jerusalem approached and the interest from the media regarding our findings was very high. However, when we analyzed our findings from the first postoperative 6 months, both the clinical assessment and the PET scans showed minimal if any improvement and no real evidence of graft survival. In the audience, which was crowded, there was a film crew from the BBC, so our presentation (by O.L.), describing a lack of improvement, was actually filmed. We were quite disappointed but the reaction to the talk from the audience was surprisingly positive, emphasizing how careful we had been performing the study and how well it was based on preclinical studies. A detailed account of the methodology and the clinical outcome in the first two patients was published in Archives of Neurology [26].
But we had to improve the transplantation procedure in order to be able to proceed. Two new PD patients were selected. Importantly, preclinical studies in rats performed by Patrik Brundin demonstrated that the survival of grafted human cells was influenced by the size of the implantation device. Based on those findings we decided to move forward with the clinical program, this time using a considerably thinner implantation cannula: $1.0 \mathrm{~mm}$ outer diameter vs $2.5 \mathrm{~mm}$ outer diameter in the previous trial, and an improved technique for loading of the cannula so that all tissue could be used. We also increased the number of implantation sites, from 2 to 3 , to be able to reinnervate the putamen more completely. Patient 3 and 4 were transplanted with VM tissue from four donors unilaterally along three tracts in the putamen on April 18 and May 26, 1989.

The patients were followed with neurological examinations by O.L. every week during the whole summer. Once a month, we monitored the response to a single dose of L-dopa. In patient 3 , it was clear that something started to happen from about three months after transplantation. The movements in the limb contralateral to the grafts were faster and rigidity less. The condition in the morning after drug withdrawal over night was improved. The effect of one L-dopa dose lasted longer. At five months after transplantation, we decided that we had to check whether the improvement could be due to a surviving graft in the patient's brain and we, therefore, travelled together with the patient for PET scanning in London. Already when we were in London, the preliminary images suggested that the grafted dopamine neurons had survived. We were extremely excited but could not believe that this was true. After a few days we got confirmation that the PET images really showed a surviving graft. This finding, that grafted cells can survive transplantation into the 50 year old human brain affected by a chronic neurodegenerative disorder and give rise to a measurable improvement, was the most exciting one in our scientific careers. When our paper was published in Science on February 2, 1990 [11], it caused an international media interest which none had anticipated. Already before the embargo had been lifted, on the evening of February 1 , Swedish television mentioned our study in the news program. CNN reported our study and articles were also published in New York Times and Washington Post. Most importantly, though, an editorial in The Lancet had the headline "A brain transplant that works." We had reached a first and very important scientific goal. 
Patient 4, who had been transplanted one week later, also did very well after surgery. He was able to withdraw his L-dopa treatment completely after three years and at 10 years after transplantation, had only mild parkinsonian symptoms. Low-dose L-dopa (one-third of preoperative dose) had been reintroduced after six years owing to progression of symptoms axially and in the limbs ipsilateral to the graft. During one of the visits that O.L. together with a talented PhD student Peter Hagell made to Hammersmith Hospital for PET-scanning with patients in 1998, we heard from our collaborator Paola Piccini that one of her colleagues at Hammersmith Hospital had been able to quantify dopamine release in vivo in the brain of a normal subject playing a video game using PET [27]. The idea directly came up that maybe it would be possible to measure dopamine release also from grafts. Patient 4, who had been grafted in the right putamen, seemed perfect for such a study because the non-operated side could serve as control. We immediately prepared an application to the ethical committee. Nobody else in the transplantation team was informed. Even if we were excited about this study, we were quite pessimistic and did not think it would work.

When approved by the ethical committee, O.L. called patient 4 and explained what we were planning to do. The patient was very enthusiastic and immediately accepted to participate. So O.L. and the patient left for London and the patient was subjected to two scans with the tracer raclopride. In one of the scans, amphetamine was first given to induce release of dopamine from the endogenous or grafted cells. In the other scan, saline was given. The degree of binding of the tracer revealed whether dopamine was released or not. High binding of raclopride meant low release and low binding high release. After we had returned to Lund, we did not hear anything from Paola and were worried that the study had failed. When we called her after several weeks, she said that the outcome was exactly as in the best scenario: the grafts had restored both spontaneous and drug-induced dopamine release in the putamen on the operated side to normal levels. In contrast, dopamine release on the non-operated side was only $10 \%$ of normal. Everything had worked!! Our article was rapidly published in Nature Neuroscience [12] and we even got cover image.

Patient 4 died 24 years after transplantation. In line with the PET findings at 10 years after surgery, we found at autopsy a dense, near-normal graftderived reinnervation of the transplanted putamen whereas the nontransplanted putamen was devoid of dopamine fibres [28]. However, the clinical benefits in this patient had been gradually lost from 14 years post-transplantation. This evolution was probably caused by the severe pathological changes that we observed in the patient's brain, including substantial atrophy and characteristic Lewy pathology in all brain regions such as limbic system and neocortex, accompanied by a gradual development of dementia. In addition, $\alpha$-synuclein-positive inclusions, some with the appearance of typical Lewy bodies, were present in $11-12 \%$ of the grafted dopaminergic neurons, probably reflecting spread of pathology from the host brain to the transplant (see below). We concluded from these findings that a rich dopamine innervation, which develops during the first three years after transplantation and gives rise to major motor improvement, can be maintained for a quarter of a century in PD. However, the clinical outcome in patient 4 demonstrates that even such a viable graft may lose its efficacy if widespread $\alpha$-synucleinopathy and major degenerative changes develop in the host brain.

\section{WHAT HAPPENED NEXT?}

The impact of our 1990 paper was two-fold: it boosted the interest in the field and it encouraged us in Lund to push ahead with the program. Over the next decade a total of 18 patients were transplanted in the Lund program. Although the outcome varied from patient to patient, the marked improvement seen in some of the grafted patients, like patients 3 and 4 above, was remarkable (see Lindvall and Hagell [29], Lindvall and Bjorklund [30] for a comprehesive review). The open label design of our program, focused on careful, long-term assessment of small numbers of patients, combined with the regular ${ }^{18}$ F-DOPA PET scans performed at the Hammersmith Hospital in London, allowed us to make steady progress. Looking back, however, the events during this period appear more like a ride on a roller-coaster, with "ups" driven by unrealistic hype, and "downs" caused by over-publicized setbacks.

The first hype was caused by a report in New England Journal of Medicine (NEJM) published in April 1987 by Ignazio Madrazo and his collagues in Mexico City [31]. In sharp contrast to the modest changes seen in the four patients operated in Stockholm and Lund (see above), this paper reported dramatically positive results in two patients that received pieces 
of adrenal medulla placed in a cavity in the head of the caudate nucleus (using an open surgical approach rather than stereotaxic surgery). This report was enthusiastically endorsed in the PD field and over the following 5 years several hundred patients received this form of surgery, in the USA and elsewhere, but regrettably many of these cases were never followed up or reported properly in the scientific literature. The more carefully conducted studies, however, failed to obtain the same dramatic improvements, and the longterm outcome of this surgery turned out to be very poor [32]. This upsurge in adrenal medullary grafting was quite damaging to the cell transplantation field. In retrospect we can see that the approach was ill conceived (relying on poor and very limited pre-clinical data), and the way the initial open-label clinical trials were conducted led to overly optimistic and poorly documented reports that paved the way for disappointment and gave the skeptics good reasons to question the credibility of the whole field.

The next upstir was linked to the appearance of three papers published back-to-back in the NEJM in November 1992, reporting interesting results in two patients with MPTP-induced parkinsonism [33], and in two groups of PD patients, 4 in each case [34, 35]. In USA the use of tissue from aborted human fetuses was highly controversial and a ban on federal funding for fetal tissue research had been introduced by the Reagan administration already in 1988. The overall promising results reported in the NEJM papers generated considerable interest and debate, and the resulting media attention may have played a role in the decision of the new president, Bill Clinton, to lift this ban in January 1993 (indeed the first made in his presidency). This opened the way for NIH to fund two sham surgery-controlled studies, the Colorado/Columbia trial and the Tampa/Mount Sinai/Rush trial, that were initiated in mid 1990ies and reported in 2001 and 2003, respectively [36, 37].

The negative outcome of these two trials was a major set-back for the whole field and convinced many of our colleagues, paticularly in the USA, that the cell transplantation approach had reached a dead-end. The wide media attention and the fact that these placebo-controlled trials were initiated and sponsored by the NIH helped to convey the impression that the outcome provided an authoritative and definitive answer: cell transplantation in PD does not work. In retrospect, however, it is clear that these trials were performed prematurely. Cell transplantation was at the time in a very early stage of development and many technical issues and problems, such as cell preparation, handling and storage, method and site(s) of implantation, patient selection, and type and extent of immunosuppressive treatment, had not been studied properly, and certainly not properly sorted out. Thus, the protocols used in the two trials were based on very limited or insufficient experience from preclinical studies. Notably, in the Colorado/Columbia study the tissue used for transplantation was stored in culture for up to four weeks, and the patients included in the Tampa/Mount Sinai/Rush trial were quite advanced in their disease, likely due to the emergence at that time of a competing surgical treatment, deep brain stimulation. Moreover, these trials used very limited immunosuppressive treatment (none in the Colorado/Columbia study) and the post-operative observation period was quite short, limited to 1 or 2 years. We know today that the clinical benefits induced by the transplants develop slowly over time, reaching full impact only after 3-5 years and that efficient immunosuppression, at least during the first postoperative year, is needed to obtain optimal graft survival. Clinical trials compromising on immunosuppression and using short end-points will thus run the risk of missing the full impact of the transplanted cells.

\section{WHERE DO WE STAND NOW?}

It is now 27 years since we obtained the first evidence that developing dopamine neuroblasts can survive and grow in the PD brain. Although we still do not know if this restorative approach can be developed into a viable and widely applicable clinical treatment, considerable progress has been made in the intervening years toward this goal. In particular, the demonstration that dopamine neuron grafts can survive, function and restore dopamine release in the putamen of PD patients, still after more than a decade, and in some cases provide long-lasting restoration of motor functions to the extent that the patients can stop taking dopaminergic medication [12, 38, 39], is an important advance. Further important insights have been made in studies of brains from grafted PD patients that have come to autopsy, showing that the grafted neurons can restore dopamine innervation to near-normal levels in the grafted putamen, and that this can be maintained for up to 24 years with no evidence of an immune response [28]. There has also been important progress in the understanding of the graft-dependent involuntary movements that 
have been observed in a subset of grafted patients (see, e.g., Politis et al. [40]), indicating that this serious side-effect may be possible to avoid by careful attention to patient selection and the composition of the grafted cell material.

Already in our planning meetings prior to the first patients were operated in 1987, we considered the possibility that the disease process might spread to the grafted dopamine neurons. If this would happen soon after surgery, the clinical usefulness of cell transplantation in PD would probably be very modest. At that time, the clinicians in our team agreed that if the grafts would provide therapeutic benefit lasting only a few years, the transplantation approach would still be therapeutically valuable and surgery would be justified. Twenty years later we obtained the first evidence that the disease can propagate from the host to the graft. In 2007, when two of our grafted patients had died of causes unrelated to the transplantation, we examined their brains to determine whether the grafts had survived. This was done together with Jia-Yi Li and Patrik Brundin. We found, concomitantly with an American group, that many years after transplantation, a fraction of the grafted dopaminergic neurons $(<2 \%$ at 11 years and $5 \%$ at 16 years post-implantation) contained Lewy bodies, the hallmark of PD [41, 42]. These findings were unexpected but has generated an enormous interest and opened up a completely new research field on the pathogenesis of PD, even suggesting a prion-like mechanism. The question soon arose whether the further development of cell transplantation in PD should be stopped. However, in our view and based on available observations in PD patients, dopamine cell therapy is still a viable therapeutic option because (i) spread of pathology is very slow, (ii) grafted neurons are unaffected after a decade, and (iii) patients can experience long-term motor improvement.

Looking back over the past 40 years we feel that the pioneering days have come to a close and that we are now entering a new chapter in the development of cell therapy for PD. There is today a new momentum and drive in the field reflecting a renewed interest in brain regeneration and cell-based repair, which is to a large degree due to the progress that has been made over the last decade in the stem cell field. A new generation of cell differentiation protocols, developed in centers in Europe, USA and Japan [43-46], have opened up entirely new possibilities to generate transplantable dopamine neurons from pluripotent stem cells with properties that are closely similar, or even identical, to the dopamine neurons residing in the midbrain of the developing fetus. With the access to such cells, generated in large numbers under conditions that allow their use in patients, we are now entering an exciting new phase in the cell transplantation field. In contrast to fetal VM tissue, which inevitably varies in age, viability, composition and quality, and is difficult to obtain in large enough amounts, stem cell-derived cell preparations promise to offer, for the first time, a cell source that is fully characterised and standardised with respect to viability, composition and potency, thus providing grafts that are identical from patient to patient. The access to such cells in large numbers will not only give new opportunities to perform more carefully designed clinical trials, but also make it possible to achieve more wide-spread reinnervation of the striatal complex than has been possible with fetal cells. The clinical trials under planning at European, US and Asian centers using cells derived from human embryonic or induced pluripotent stem cells will open a new chapter in the history of cell-based brain repair. Their outcome will not only help us to clarify the possible therapeutic value of the cell replacement approach, but may also represent an important step in the development of a stem cell-based product that could be offered for routine use in PD patients.

\section{ACKNOWLEDGMENTS}

Our program in Lund has been entirely dependent on academic funding. The initiation of the early clinical trials using fetal VM tissue from aborted fetuses was made possible not only by research grants from a number of local foundations, but most critically by the sustained support we received the Swedish Medical Research Council, the Bank of Sweden Tricentenary Fund and the Torsten and Ragnar Söderberg Foundations. We are grateful for the willigness of these funding agencies to maintain active support of our program despite its ups and downs and its ethically sensitive nature.

\section{CONFLICT OF INTERESTS}

The authors declare no conflict of interest related to this work.

\section{REFERENCES}

[1] Falck B, Hillarp NÅ, Thieme G, Torp A (1962) Fluorescence of Catechol Amines and Related Compounds Condensed With Formaldehyde. J Histochem Cytochem, 10, 348-354. 
[2] Ungerstedt U, \& Arbuthnott GW (1970) Quantitative recording of rotational behavior in rats after 6-hydroxydopamine lesions of the nigrostriatal dopamine system. Brain Res, 24, 485-493.

[3] Olson L, \& Seiger A (1972) Brain tissue transplanted to the anterior chamber of the ey. 1. Fluorescence histochemistry of immature catecholamine and 5-hydroxytryptamine neurons reinnervating the rat iris. Z Zellforsch Mikrosk Anat, 135, 175-194.

[4] Das GD, \& Altman J (1971) Transplanted precursors of nerve cells: Their fate in the cerebellums of young rats. Science, 173, 637-638.

[5] Stenevi U, Bjorklund A, \& Svendgaard NA (1976) Transplantation of central and peripheral monoamine neurons to the adult rat brain: Techniques and conditions for survival. Brain Res, 114, 1-20.

[6] Bjorklund A, Stenevi U, \& Svendgaard N (1976) Growth of transplanted monoaminergic neurones into the adult hippocampus along the perforant path. Nature, 262, 787-790.

[7] Bjorklund A, \& Stenevi U (1977) Reformation of the severed septohippocampal cholinergic pathway in the adult rat by transplanted septal neurons. Cell Tissue Res, 185, 289-302.

[8] Bjorklund A, Segal M, \& Stenevi U (1979) Functional reinnervation of rat hippocampus by locus coeruleus implants. Brain Res, 170, 409-426.

[9] Bjorklund A, \& Stenevi U (1979) Reconstruction of the nigrostriatal dopamine pathway by intracerebral nigral transplants. Brain Res, 177, 555-560.

[10] Bjorklund A, Stenevi U, Schmidt RH, Dunnett SB, \& Gage FH (1983) Intracerebral grafting of neuronal cell suspensions. Part I-V. Acta Physiol Scand Supplement, 522, 1-47.

[11] Lindvall O, Brundin P, Widner H, Rehncrona S, Gustavii B, Frackowiak R, Leenders KL, Sawle G, Rothwell JC, Marsden CD, et al. (1990) Grafts of fetal dopamine neurons survive and improve motor function in Parkinson's disease. Science, 247, 574-577.

[12] Piccini P, Brooks DJ, Bjorklund A, Gunn RN, Grasby PM, Rimoldi O, Brundin P, Hagell P, Rehncrona S, Widner H, \& Lindvall O (1999) Dopamine release from nigral transplants visualized in vivo in a Parkinson's patient. Nat Neurosci, 2, 1137-1140.

[13] Bjorklund A, Dunnett SB, Stenevi U, Lewis ME, \& Iversen SD (1980) Reinnervation of the denervated striatum by substantia nigra transplants: Functional consequences as revealed by pharmacological and sensorimotor testing. Brain Res, 199, 307-333.

[14] Perlow MJ, Freed WJ, Hoffer BJ, Seiger A, Olson L, \& Wyatt RJ (1979) Brain grafts reduce motor abnormalities produced by destruction of nigrostriatal dopamine system. Science, 204, 643-647.

[15] Freed WJ, Morihisa JM, Spoor E, Hoffer BJ, Olson L, Seiger A, \& Wyatt RJ (1981) Transplanted adrenal chromaffin cells in rat brain reduce lesion-induced rotational behaviour. Nature, 292, 351-352.

[16] Bjorklund A, Stenevi U, Dunnett SB, \& Iversen SD (1981) Functional reactivation of the deafferented neostriatum by nigral transplants. Nature, 289, 497-499.

[17] Dunnett SB, \& Iversen SD (1982) Sensorimotor impairments following localized kainic acid and 6hydroxydopamine lesions of the neostriatum. Brain Res, 248, 121-127.
[18] Bjorklund A, Schmidt RH, \& Stenevi U (1980) Functional reinnervation of the neostriatum in the adult rat by use of intraparenchymal grafting of dissociated cell suspensions from the substantia nigra. Cell Tissue Res, 212, 39-45.

[19] Schmidt RH, Bjorklund A, \& Stenevi U (1981) Intracerebral grafting of dissociated CNS tissue suspensions: A new approach for neuronal transplantation to deep brain sites. Brain Res, 218, 347-356.

[20] Brundin P, Isacson O, \& Bjorklund A (1985) Monitoring of cell viability in suspensions of embryonic CNS tissue and its use as a criterion for intracerebral graft survival. Brain Res, 331, 251-259.

[21] Brundin P, Nilsson OG, Strecker RE, Lindvall O, Astedt B, \& Bjorklund A (1986) Behavioural effects of human fetal dopamine neurons grafted in a rat model of Parkinson's disease. Exp Brain Res, 65, 235-240.

[22] Brundin P, Strecker RE, Widner H, Clarke DJ, Nilsson OG, Astedt B, Lindvall O, \& Bjorklund A (1988) Human fetal dopamine neurons grafted in a rat model of Parkinson's disease: Immunological aspects, spontaneous and druginduced behaviour, and dopamine release. Exp Brain Res, 70, 192-208.

[23] Clarke DJ, Brundin P, Strecker RE, Nilsson OG, Bjorklund A, \& Lindvall O (1988) Human fetal dopamine neurons grafted in a rat model of Parkinson's disease: Ultrastructural evidence for synapse formation using tyrosine hydroxylase immunocytochemistry. Exp Brain Res, 73, 115-126.

[24] Backlund EO, Granberg PO, Hamberger B, Knutsson E, Martensson A, Sedvall G, Seiger A, \& Olson L (1985) Transplantation of adrenal medullary tissue to striatum in parkinsonism. First clinical trials. J Neurosurg, 62, 169-173.

[25] Lindvall O, Backlund EO, Farde L, Sedvall G, Freedman R, Hoffer B, Nobin A, Seiger A, \& Olson L (1987) Transplantation in Parkinson's disease: Two cases of adrenal medullary grafts to the putamen. Ann Neurol, 22, 457-468.

[26] Lindvall O, Rehncrona S, Brundin P, Gustavii B, Astedt B, Widner H, Lindholm T, Bjorklund A, Leenders KL, Rothwell JC, Frackowiak R, Marsden D, Johnels B, Steg G, Freedman R, Hoffer BJ, Seiger A, Bygdeman M, Stromberg I, \& Olson L (1989) Human fetal dopamine neurons grafted into the striatum in two patients with severe Parkinson's diseas. A detailed account of methodology and a 6-month follow-up. Arch Neurol, 46, 615-631.

[27] Koepp MJ, Gunn RN, Lawrence AD, Cunningham VJ, Dagher A, Jones T, Brooks DJ, Bench CJ, \& Grasby PM (1998) Evidence for striatal dopamine release during a video game. Nature, 393, 266-268.

[28] Li W, Englund E, Widner H, Mattsson B, van Westen D, Latt J, Rehncrona S, Brundin P, Bjorklund A, Lindvall O, \& Li JY (2016) Extensive graft-derived dopaminergic innervation is maintained 24 years after transplantation in the degenerating parkinsonian brain. Proc Natl Acad Sci U S A, 113, 65446549.

[29] Lindvall O, \& Hagell P (2000) Clinical observations after neural transplantation in Parkinson's disease. Prog Brain Res, 127, 299-320.

[30] Lindvall O, \& Bjorklund A (2004) Cell therapy in Parkinson's disease. NeuroRx, 1, 382-393.

[31] Madrazo I, Leon V, Torres C, Aguilera MC, Varela G, Alvarez F, Fraga A, Drucker-Colin R, Ostrosky F, Skurovich M, et al. (1988) Transplantation of fetal substantia nigra and adrenal medulla to the caudate nucleus in two patients with Parkinson's disease. N Engl J Med, 318, 51. 
[32] Goetz CG, Stebbins GT 3rd, Klawans HL, Koller WC, Grossman RG, Bakay RA, \& Penn RD (1991) United Parkinson Foundation Neurotransplantation Registry on adrenal medullary transplants: Presurgical, and 1- and 2year follow-up. Neurology, 41, 1719-1722.

[33] Widner H, Tetrud J, Rehncrona S, Snow B, Brundin P, Gustavii B, Bjorklund A, Lindvall O, \& Langston JW (1992) Bilateral fetal mesencephalic grafting in two patients with parkinsonism induced by 1-methyl-4-phenyl-1,2,3,6tetrahydropyridine (MPTP). N Engl J Med, 327, 1556-1563.

[34] Freed CR, Breeze RE, Rosenberg NL, Schneck SA, Kriek E, Qi JX, Lone T, Zhang YB, Snyder JA, Wells TH, et al. (1992) Survival of implanted fetal dopamine cells and neurologic improvement 12 to 46 months after transplantation for Parkinson's disease. N Engl J Med, 327, 1549-1555.

[35] Spencer DD, Robbins RJ, Naftolin F, Marek KL, Vollmer T, Leranth C, Roth RH, Price LH, Gjedde A, Bunney BS, et al. (1992) Unilateral transplantation of human fetal mesencephalic tissue into the caudate nucleus of patients with Parkinson's disease. N Engl J Med, 327, 1541-1548.

[36] Freed CR, Greene PE, Breeze RE, Tsai WY, DuMouchel W, Kao R, Dillon S, Winfield H, Culver S, Trojanowski JQ, Eidelberg D, \& Fahn S (2001) Transplantation of embryonic dopamine neurons for severe Parkinson's disease. $N$ Engl $J$ Med, 344, 710-719.

[37] Olanow CW, Goetz CG, Kordower JH, Stoessl AJ, Sossi V, Brin MF, Shannon KM, Nauert GM, Perl DP, Godbold J, \& Freeman TB (2003) A double-blind controlled trial of bilateral fetal nigral transplantation in Parkinson's disease. Ann Neurol, 54, 403-414.

[38] Piccini P, Lindvall O, Bjorklund A, Brundin P, Hagell P, Ceravolo R, Oertel W, Quinn N, Samuel M, Rehncrona S, Widner H, \& Brooks DJ (2000) Delayed recovery of movement-related cortical function in Parkinson's disease after striatal dopaminergic grafts. Ann Neurol, 48, 689-695.

[39] Kefalopoulou Z, Politis M, Piccini P, Mencacci N, Bhatia K, Jahanshahi M, Widner H, Rehncrona S, Brundin P, Bjorklund A, Lindvall O, Limousin P, Quinn N, \& Foltynie T
(2014) Long-term clinical outcome of fetal cell transplantation for Parkinson disease: Two case reports. JAMA Neurol, 71, 83-87.

[40] Politis M, Wu K, Loane C, Quinn NP, Brooks DJ, Rehncrona S, Bjorklund A, Lindvall O, \& Piccini P (2010) Serotonergic neurons mediate dyskinesia side effects in Parkinson's patients with neural transplants. Sci Transl Med, 2, 38ra46.

[41] Li JY, Englund E, Holton JL, Soulet D, Hagell P, Lees AJ, Lashley T, Quinn NP, Rehncrona S, Bjorklund A, Widner H, Revesz T, Lindvall O, \& Brundin P (2008) Lewy bodies in grafted neurons in subjects with Parkinson's disease suggest host-to-graft disease propagation. Nat Med, 14, 501-503.

[42] Kordower JH, Chu Y, Hauser RA, Freeman TB, \& Olanow CW (2008) Lewy body-like pathology in long-term embryonic nigral transplants in Parkinson's disease. Nat Med, 14, 504-506.

[43] Kriks S, Shim JW, Piao J, Ganat YM, Wakeman DR, Xie Z, Carrillo-Reid L, Auyeung G, Antonacci C, Buch A, Yang L, Beal MF, Surmeier DJ, Kordower JH, Tabar V, \& Studer L (2011) Dopamine neurons derived from human ES cells efficiently engraft in animal models of Parkinson's disease. Nature, 480, 547-551.

[44] Kikuchi T, Morizane A, Doi D, Onoe H, Hayashi T, Kawasaki T, Saiki H, Miyamoto S, \& Takahashi J (2011) Survival of human induced pluripotent stem cell-derived midbrain dopaminergic neurons in the brain of a primate model of Parkinson's disease. J Parkinsons Dis, 1, 395-412.

[45] Kirkeby A, Grealish S, Wolf DA, Nelander J, Wood J, Lundblad M, Lindvall O, \& Parmar M (2012) Generation of regionally specified neural progenitors and functional neurons from human embryonic stem cells under defined conditions. Cell Rep, 1, 703-714.

[46] Sundberg M, Bogetofte H, Lawson T, Jansson J, Smith G, Astradsson A, Moore M, Osborn T, Cooper O, Spealman R, Hallett P, \& Isacson O (2013) Improved cell therapy protocols for Parkinson's disease based on differentiation efficiency and safety of hESC-, hiPSC-, and non-human primate iPSC-derived dopaminergic neurons. Stem Cells, 31, 1548-1562. 